\title{
The Importance of Bilateral Agreement on Mandatory Consular Notification for Indonesia: Tuti Tursilawati Execution
}

\author{
Yordan Gunawan ${ }^{1}$, Zulfiani Ayu Astutik ${ }^{2}$ \\ ${ }^{1}$ Faculty of Law, Universitas Muhammadiyah Yogyakarta, Indonesia \\ yordangunawan@umy.ac.id \\ ${ }^{2}$ Faculty of Law, Universitas Muhammadiyah Yogyakarta, Indonesia \\ zulfianiayuastutik@yahoo.com
}

\begin{abstract}
Introduction to The Problem: The execution without notification of Tuti Tursilawati's at the end of 2018 becomes one of the most important diplomatic and consular relations issues between Indonesia and Saudi Arabia. Indonesia was unable to seek Saudi Arabia clarification because of the absence of bilateral agreement regarding consular notification between Indonesia and Saudi Arabia. Having regard to the Vienna Convention on Diplomatic Relations 1961 and the Vienna Convention on Consular Relations 1963, both provides the protection and assistance from the Consulate to all their citizens abroad.

Purpose/Objective Study: This research aims to outline the importance of bilateral agreement on the mandatory consular notification in dealing with a case of Tuti Tursilawati who executed by Saudi Arabia government without any notification to the Republic of Indonesia.
\end{abstract}

Design/Methodology/Approach: Data was collected from primary and secondary data sources in the form of literature legal research and statute approach.

Findings: The result shows that based on Article 36 of the VCCR 1963, Mandatory Consular Notification should be delivered by Saudi Arabia before the execution. Making a bilateral agreement on Mandatory Consular Notification (MCN) with Saudi Arabia is very urgent to become a legal basis in helping and giving proper protection to the Indonesian who lives in Saudi Arabia in the future. Without that agreement, Indonesia will be not easy to access the information and assisting to protect the rights of the nationals from any cases that happened abroad, especially related to criminal issues.

Paper Type: Research Article

Keywords: Bilateral Agreement; Execution Without Notification; Mandatory Consular Notification; Tuti Tursilawati

\section{Introduction}

Every day, people are executed and sentenced to death by the state as a punishment for a variety of crimes, such as drug-related offenses, terrorism-related acts, and murder. Some countries use the death penalty against people with mental and 


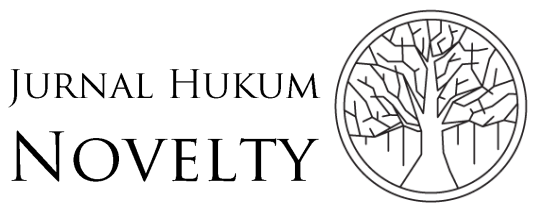

Volume 10, Issue 02, 2019, pp. 85-100
P-ISSN: $1412-6834$

E-ISSN: 2550-0090

intellectual disabilities. It is discussed a lot in every platform, starting from a national level like in the government institutions, journalism, and the international world and also in society.

Iran, Saudi Arabia, Iraq, and Pakistan are listed as the four highest countries which held executions. In general, these four countries accounted for 84 percent of all executions in the world (Amnesty International, 2018). Iran became the top with 507 people sentenced to death executed, with most of them being convicts of drug cases and convicts of drug cases experienced 264 executions in the Middle East and North Africa. While in Saudi Arabia, 40 percent of the death sentences were handed down to suspects with similar cases. According to Amnesty International researcher Oluwatosin Popoola, the death penalty carried out in the Middle East and North Africa does not meet international standards and is classified as arbitrary (Amnesty International, 2019).

There are a lot of cases about the death penalty, which involved many people. According to Migrant Care records, $72 \%$ of migrant workers who face the death penalty are women. The data of the Ministry of Foreign Affairs in 2011- 2017 collected 188 cases of Indonesian citizens threatened with the death penalty in the process of handling, and 392 instances completed with a free sentence. The consular notification is essential for Indonesia, considering that many foreign nationals are in trouble and face the death penalty. For example, from January 1 to October 2014, the Directorate of PWNI and BHI received 13,780 case reports received from the public. The case is divided into several issues, namely Indonesian citizens who are threatened with the death penalty of several countries for murder crimes (31.38\%), drug smuggling (61.09\%), adultery (3.77\%), and others.

Again, the Government of Saudi Arabia executes Indonesian Workers (TKI). The migrant worker was named Tuti Tursilawati from Majalengka West Java who was sentenced to death, on Monday, October 29th, 2018 in Thaif. Tuti Tursilawati was arrested by the Saudi Police on charges of murdering Suud Mulhaq Al-Utaibi, father of her boss. She is known to have worked for eight months with the remaining salary not paid for six months. After killing the victim, Tuti fled to Makkah carrying jewelry and money. However, on the way to escape to Makkah, she raped nine Saudi youth and took all of her stolen goods. The nine young men were arrested and have been punished by Saudi legal provisions. During the investigation process, Tuti Tursilawati admitted that she had killed her father boss because of frequent sexual harassment.

The large number of Indonesia Migrant Worker cases that do not have consular access is one proof that Indonesia's diplomatic efforts in Saudi Arabia are not an easy matter. Every country that violates the protection of foreigners can cause international responsibility. So far there are two kinds of theories of state treatment of foreigners, namely the International Minimum Standard and National Minimum Standard. Starting from the importance of protecting foreigners, some developed countries such 
as the United States want an international minimum standard in the treatment of foreigners and the interest. According to this theory, standards do not only include law but also enforcers.

On the other hand, each developing country has its own minimum standards regarding the treatment of foreigners who are then referred to as the National Minimum Standard. This principle is based on Article 9 of the 1933 Montevideo Convention which states that: Nationals and foreigners are under the same protection of the law and the national authorities, and are more extensive than those of the nationals. So according to this principle, the state will treat the same between foreigners and their citizens. Generally, this understanding is used to avoid undesirable interventions from stronger countries. Based on the explanation above, it can be seen that there are conflicts between developed countries and developing countries regarding the treatment of foreigners (Abass, 2014). For this reason, the Gracia Anador summarizes that the minimum standard of a country is the protection of human rights as also stated in Universal Declaration of Human Rights H. Waldock mentions that what is meant by Human Rights here is rights which attaches to all human beings equally, whatever their nationality.

Saudi Arabia possibly defend their decision by using Territorial Principle, this principle means that every State has their own authority to execute any crimes committed in its own territory. However, Indonesia also has a right to protect the citizens whenever they live as known as Nationality Principle.

Protecting citizens who get problems abroad is one of the country's obligations. Meeting these special obligations is not an easy task for the State. Therefore, all countries must prioritize this task. Including Indonesia as one of the countries, which has many citizens who live and work abroad. On Preamble of the 1945 and Article 19 (b) Law No. 37 of 1999 concerning Indonesian Foreign Relations said that the State has the responsibility to protect the honor and property of Indonesian citizens living abroad.

Because of it, there are so many countries establish a consular relation with another country around the world (Sen, 1965). In dealing with this problem, most countries refer to existing international conventions such as the Vienna Convention on Consular Relation 1963 on Diplomatic Relations and the Vienna Convention on Consular Relations 1963 on Consular Relations (VCCR) ratified by Indonesia in Law Number 1 of 1983. This Vienna Convention guarantees consular assistance and access from each country to their citizens who may need assistance when traveling, working, or living abroad. Consular access is found in Article 36 of the Vienna Convention on Consular Relations 1963. On the other hand, Article 36 of the Vienna Convention on Consular Relations 1963 stipulates the mechanism of Consul can help the citizens who have been arrested or detained in other countries that have received VCCR 1963. There are still many problems abroad and the citizens still fail to get access for help and 


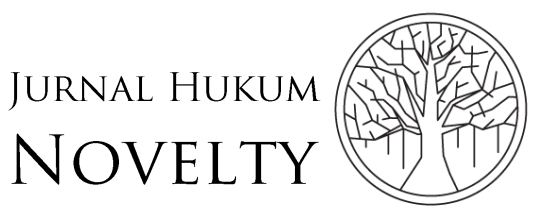

Volume 10, Issue 02, 2019, pp. 85-100
P-ISSN: $1412-6834$

E-ISSN: 2550-0090

protection. In line with the previous background, it is interesting to evaluate the importance of bilateral agreement on mandatory consular notification for Indonesia in dealing with Tuti Tursilawati death penalty.

\section{Methodology}

The type of this research is a normative legal research method. This research uses secondary data and normative methods combined to case and statute approach in analyzing the issue of bilateral agreement on mandatory consular notification. The statute approach is conducted by highlighting some regulations that related to the issues while the case approach is conducted by reviewing the case that related to the issues.

The author collected the data from the legal literature, focusing on a reading and analysis of the primary and secondary materials (such as legal dictionaries, textbooks, journal articles, case digests, and legal encyclopedias). Source of data in this research were collected by secondary data method. It is a method of research to collect data from the legal literature research.

The data were collected by library research such reading, analysing, and deriving conclusion from related documents (law books, legal journals, internets and other related to the main problem of this research).

The data were analyzed systematically through descriptive qualitative method which means that collecting the data and selecting the data obtained from research with the focus on the problem and then the result was arranged systematically so that it becomes concrete data.

\section{Results and Discussion}

\section{Bilateral Agreement}

Currently, inter-state cooperation can no longer be avoided. Complex forms of life are very vulnerable to disputes. To avoid that disputes do not occur, the international community must always obey the norms and rules. These rules are not only made to avoid disputes but also to discipline, regulate, and maintain the relations between or among countries (Shaw, 2003).

The embodiment of the cooperation is stated in the form of agreement. The international agreement can be classified into four types, namely an International agreement in terms of the number of participants; International agreement in terms of the legal rules that it creates; International agreement in terms of the procedure or stage of its formation; International agreement in terms of the period of validity.

One of the agreements between countries is distinguished based on the number of members of the agreement, and the types is a bilateral agreement. Bilateral itself comes from the word 'bi', which means two, so it can be said that bilateral is an agreement between two countries. 
Legal rules from bilateral agreement are specific and closed treaty, meaning that both parties must fully or completely obey all the contents or articles of the agreement or do not want to submit at all, so that the agreement will never be binding and apply as positive law, and the agreement only apply for the two concerned parties. The member of parties in this agreement is not specified. This is because a bilateral agreement is more about personal than other agreements because just two parties involved.

\section{Mandatory Consular Notification in the Diplomatic and Consular Relations within the State}

Consular relations between sovereign states have existed for centuries (Faro \& Moraru, 2010). Before the adoption of the Vienna Convention on Consular Relations 1963, the guidelines governing consular relations derived generally from customary performs advanced over time and through bilateral consular agreement. The right and the duty of Consuls to defend their citizens abroad have been perceived by U.S. Law for nearly 200 years.

During the 1950s, the international community perceived the need to systematize the current guidelines and works on administering consular relations. Henceforth, the General Assembly of the United Nations entrusted the International Law Commission to draft a multilateral treaty to carry greater consistency to the law of consular relations. The Vienna Convention on Consular Relations 1963 came about because of that procedure. Its last content was closed and opened for mark in 1963, yet it didn't go into power until 1967.

As known in the previous discussion that the task of protection is more carried out in consular functions with the legal basis of the Vienna Convention on Consular Relations 1963 ("MEDELLIN v. TEXAS | LII / Legal Information Institute," n.d.). The Convention on Consular Relations 1963 also gives freedom to the state to form agreements related to diplomatic protection for its citizens. At first, the protection of citizens was carried out with consular notices as stipulated in Article 36 of the Vienna Convention on Consular Relations 1963.

Nevertheless, many countries violated the provisions of this article, which ultimately formed a more specific agreement. The country applies its national laws to foreigners without giving notifications to consular representatives in their countries. This kind of thing indeed has injured the rights of foreign citizens in the form of assistance, assistance from translators, and so forth. Mandatory Consular Notification was first initiated by the United States of America (Gustina, 2014).

However, the US was proven to have repeatedly violated Article 36 of the Vienna Convention on Consular Relations 1963 against foreigners who committed crimes in their territory. The violation occurred even though the United States had ratified the Vienna Convention on Consular Relations in 1963 in 1969 (Buys, 2010). The violations of the United States will be described in the following cases: 


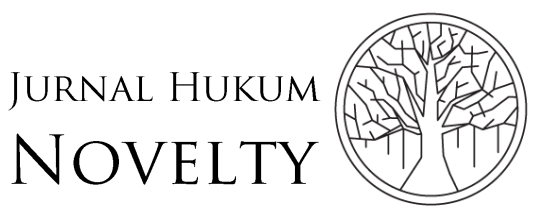

Volume 10, Issue 02, 2019, pp. 85-100
P-ISSN: $1412-6834$

E-ISSN: 2550-0090

1. The case of La Grand (the United States vs Germany)

In the case of La Grand which occurred in 1986, the United States sentenced Karl La Grand and Walter La Grand, two German citizens who were charged with the murder of bank officers and attempted robbery in the state of Arizona. The following year, the two La Grand brothers were found guilty and sentenced to death. Germany then tried to reopen the case and settle it through diplomatic channels but was rejected by the United States. In 1999 the United States carried out the execution of Karl La Grand. The day after the execution was carried out, Germany submitted a motion for temporary action to the International Court of Justice (ICJ). The day after the submission of the motion, ICJ called on the United States to postpone the execution of Walter La Grand until there was a further verdict. Germany filed a lawsuit against the United States in the argument that the United States had failed to notify the German government by Article 36 of The Vienna Convention on Consular Relations 1963 (ICJLa Grand Case.pdf, n.d.).

\section{Breard Case (the United States vs Paraguay)}

In the case of Breard which occurred in 1992, the United States sentenced Angel Francisco Breard, a citizen of Paraguay to death for alleged murder and attempted rape of US citizens Ruth Dickie. Virginia Police found Angel Breard's passport, but the US government advised the court to hide the discovery of the passport. Also, the United States does not allow the Consular Official of Paraguay to aid Angel Breard. At the first trial, Angel Breard was sentenced to fine and death sentence. After that Angel Breard proposed Habeas Relief and stated that the United States allegedly violated the Vienna Convention on Consular Relations 1963 at the time of its previous arrest by not informing itself that as citizens of Paraguay he had the right to contact his country's consular officer.

\section{The Avena Case (the United States vs Mexico)}

In the case of Avena that occurred in 2003, the United States through several states of California, Texas, Illinois, Arizona, Florida, Ohio, Nevada, Oklahoma, and Oregon sentenced 54 Mexican citizens to death. The imposition of the death sentence was carried out without consular notice to Mexico's diplomatic and consular representatives in the United States (Ariadno \& Rizani, 2006). Against this punishment, the Mexican government finally brought the case to the International Court of Justice because the United States violated Articles 36 and 37 of the Vienna Convention on Consular Relations 1963 concerning diplomatic notice and the provision of consular protection to German citizens.

As well known, international law does not have an executive body to enforce sentences, so the ICJ can only decide that the United States has violated international law, paid compensation, and gave orders to review the verdict, but could not change the death penalty dropped by the United States because it contradicts the principle of sovereignty, it can be seen that the two countries must base foreign relations on every issue involving citizens of other countries. Violations of the provisions of the 
convention by other parties do not cause a loss of the obligation of the party to implement the provisions of the convention.

From that history, the United States then decided to form a separate agreement which was later called Mandatory Consular Notification. Until now, the United States has a Mandatory Consular Notification agreement with 57 countries. This agreement was then imitated by almost all countries in the world to maximize protection for citizens who are abroad.

The right to get notifications and access is reflected in Article 36 of the Vienna Convention on Consular Relations 1963, which was widely accepted as an international practice standard by participating countries and not participating countries. This is because the Convention is based on the beliefs of countries, as well as those held in the Preamble, that the convention is a contribution as development or friendly relationship between countries. However, this is not affected by the constitutionality of different countries. There are several functions of consular relating to nationals of the sending State:

1. Consular officers shall be permitted to communicate with citizens of the sending State and to have access to them. Citizens of the sending state shall have the similar freedom with and access to consular officers of the sending state;

2. The capable authorities of the receiving state without delay to notify the consular of the sending state that the citizens are arrested or committed to prison or custody pending trial or is detained in any other manner.

3. Consular officers shall have the right to visit their citizens of the sending state who is in prison, guardianship or detention, to converse and correspond with him and to arrange for his legal representation. They shall also have the right to visit any national of the sending state who is in prison, custody or detention in their district in pursuance of a judgment. Nevertheless, consular officers shall refrain from acting on behalf of a national who is in prison, custody or detention of the expressly opposes such action.

In Article 36 of the VCCR 1963, then by many countries more specialized in a separate agreement which was then called Mandatory Consular Notification or consular notification. The Vienna Convention on Consular Relations 1963 did not specify in detail the definition or work system of the Mandatory Consular Notification. However, Article 36 of the Vienna Convention on Consular Relations 1963 can be interpreted so that it can be concluded that consular notifications are:

1. Consular notification is accommodations that give by international law to the Consul or consular officers of the sending States to communicate with their nationals in the receiving States; and

2. Consular notification is rights of citizens who arrested and detention to get help from the Consul. 


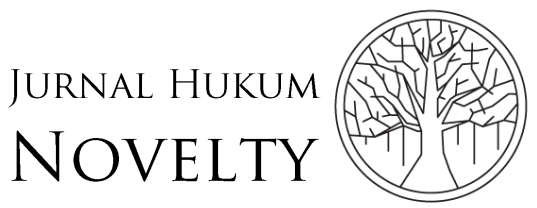

Volume 10, Issue 02, 2019, pp. 85-100
P-ISSN: $1412-6834$

E-ISSN: 2550-0090

From these definitions above, determine that consular notification is a formal statement of fact or actions concerning nationals. Consular notification is not always about deaths, guardianship or trusteeship, wrecks, and air accidents, birth, and insurance, but also concerning detention or arrest. Regarding the basis of the formation of the Mandatory Consular Notification, there are implicitly no conventions governing the establishment of this agreement. Mandatory Consular Notification is a freedom for the state, which is formed by agreement and outlined in the form of a written agreement. With the written form of Mandatory Consular Notification certainly brings its consequences, namely a consular notification is more compulsory, and its implementation is carried out without regard to the request of the country concerned. The implementation of consular notification in the Mandatory Consular Notification is different from Article 36 of The Vienna Convention on Consular Relations 1963 which is optional base, where consular notification is only needed if there is a request from that foreign country.

Mandatory Consular Notification will maximize the implementation of procedures and details of the Vienna Convention on Consular Relations 1963. A consular notification based on the Vienna Convention on Consular Relations 1963 has three principles, namely:

1. Principle of Obligation: What distinguishes the existence of a Mandatory Consular Notification agreement is the level of state obligations. The state has more binding obligations regarding the delivery of notification of the occurrence of arrests and detention without delay.

2. Pacta Sunt Servanda Principle: The emergence of a Mandatory Consular Notification is based on a binding agreement between the sending country and the recipient country, either before or after the investigation.

3. Reciprocity Principle: The state, through its consular officer, must notify consular notifications with certainty, and treat foreigners with equal treatment when arrested and detained. In this case, Indonesia will be represented by the Ministry of Foreign Affairs and the Directorate of Indonesian Citizens Protection and Indonesian Legal Entities. The consular officer must also ensure that the country does the same.

\section{The Importance of Mandatory Consular Notification for Indonesia and other Foreign Countries}

\section{The Urgency in Implementing Mandatory Consular Notification}

Indonesia is a state which has numerous residents who are working, living, and having education abroad, due to that is very importance to create Mandatory Consular Notification with other states. The Mandatory Consular Notification will provide guarantees for respectable consular notification procedures to all countries that have ratified Article 36 of the VCCR 1963 (Johnson \& Zimring, 2009). The consequences of implementing mandatory consular notification are citizens able to get consular access from consular officers without delay. 
Consular notice turns out to be compulsory if there is an agreement between two nations. A consular officer shall be informed, without reference to interest or demand of the arrested citizen. Consular notification exclusively can guarantee the Indonesian Government's capacity to ensure its residents, in addition, it can prevent unnecessary cases that will happened. Consular relations have several capacities that is changed surely and incorporate the security of the interests of the sending state, and it's national. Namely:

1. Defending the interest of sending State in the receiving state, both in people and bodies corporate, inside the points of confinement allowed by international law.

2. Promoting the development of business, monetary, social, and reasonable relations between the receiving state and the sending state;

3. Determining legitimate conditions and advancement in the business, monetary, social and explicit existence of the receiving state;

4. Issuing travel reports and identifications to citizens of the sending state, and suitable records or visas to people asking to make a trip to sending state;

5. Assisting and helping the citizens;

6. Representing as legal official and civil register;

After getting consular notifications, the residents will get consular access. There are several Consular Access Rights, such as:

1. Consular visits. Under conditions requiring notice, or when a foreign national is kept in a military restriction office, the Consul has the privilege to visit the citizens immediately. Visits will be managed by imprisonment office guidelines.

2. To communicate among Consul and the citizens. Whether or not a foreign national is confined, he will reserve a privilege to convey orally, telephonically, or recorded as a hard copy with the consul.

3. The consul will give full chance to defend the interests of the residents. The consul has right to meet, to advise, to coordinate legal representation. The consul or other authorities of the foreign nation will be treated with the dignity and civility according to his office.

\section{Obstacles in the Implementation of Mandatory Consular Notification}

Discussing Mandatory Consular Notification likewise identified with the receiving States and sending States. Mandatory Consular Notification is an international convention (bilateral agreement) that have several barriers, such as:

1. Reciprocity Principle

The reciprocity principle is one of the barriers, because qualified officers ensures that the Mandatory Consular Notification has been carried out if the citizen has the same treatment when they get a consular problem.

2. Good Faith

Mandatory Consular Notification is an international convention (bilateral agreement), good faith is an important point. If the two countries don't do the Mandatory Consular Notification as well as they do, the Mandatory Consular Notification won't work well too. 
The principle of good faith is based on the principle of Pacta Sunt Servanda as contained in the 1969 Vienna Convention concerning the Agreement Law Article 26 of the 1969 Vienna Convention concerning the Agreement Law. If a country does not implement the principle of good faith in their country, then the Mandatory Consular Notification function determination not run well. For example, Malaysia still provides ill-treatment for citizens there even though Indonesia have an MoU on the Government of Indonesia and Malaysia signing the first MoU in 1998 and the second on May 10, 2004, to regulate labor migration.

3. Unfilled of Law concerning Protection of Workers Abroad

It is still very rare to find people who speak in the field of protection, especially for Indonesian workers abroad. There should be detailed rules regarding labor abroad ranging from departure to arrival in the destination country.

4. The Unpreparedness of Indonesian Consular Officers about Mandatory Consular Notification

The Mandatory Consular Notification agreement is a new agreement for Indonesia. This is why Indonesia is not too ready to implement this agreement. In terms of technological readiness, Indonesian telecommunications technology is still undeveloped if it is considered with a difference in time and geographical location of Indonesia that is wide and separate between sea and land. In terms of Indonesia, not all officers know about consular functions, and Mandatory Consular Notifications are a separate obstacle. For example, all police officers in West Sumatra must know about consular notification because it can be ascertained there has never been an explanation beforehand.

5. Differences in language and culture between Indonesia and abroad;

Culture is a basis that will indirectly form a legal system that is different from one country to another. An example is the culture of the kafalah system in Saudi Arabia which considers that every worker is part of the employer's property. This kind of assumption causes some rules such as domestic workers not to leave the house, so they cannot return to their home countries without permission from their employers. A culture like this often joins the performance of consular officers in carrying out their obligations. She was confirmed incapable to raise her child in the state of Mississippi because the Spanish interpreter could not speak with her. But Ms. Cruz could not understand the interpreter because she only communicates an indigenous tongue. Her lack of interaction and understanding was interpreted as a mental disability.

6. Partner countries have not been willing to cooperate in the Mandatory Consular Notification field with Indonesia;

The willingness of other countries to form Mandatory Consular Notification with Indonesia is one of the biggest factors that inhibit the formation of Mandatory Consular Notifications. So far, partner countries have been reluctant to form Mandatory Consular Notifications with Indonesia because the obligation to provide consular notifications has been written in the Vienna Convention on Consular Relations 1963. For this reason, Indonesia must be able to convince 
partner countries to cooperate in the Mandatory Consular Notification field. One of the differences in the legal system between Indonesia and partner countries is the existence of the Privacy Act policy. In certain countries still, have a Privacy Act policy that serves to protect the confidentiality of its citizens or foreign nationals. While the establishment of the Mandatory Consular Notification, the Privacy Act policy must be excluded, which partner countries often do not want to do.

7. Differences in the legal system between Indonesia and other foreign countries lead to differences in understanding of the points in the Mandatory Consular Notification.

\section{Development of Protection Functions through International Law Commission (ILC) Draft Articles on Diplomatic Protection 2006}

As discussed in the previous point, that has become the duty of a country to protect its citizens abroad. Protection carried out through diplomatic channels is called diplomatic protection. While the concepts and legal basis regarding diplomatic protection itself cannot be found clearly in various international conventions (Klabbers, 2012).

The International Law Commission also codifies various provisions that have not been regulated in detail. Some of the provisions to date that are still in the draft form include the ILC Draft Articles on the State Responsibility of States for the International Wrongful Act 2001, the ILC Draft Articles on Diplomatic Protection 2006, and the ILC Draft Articles on the Responsibility of International Organizations 2011.

Before the ILC Draft Articles on Diplomatic Protection 2006, the function of protecting citizens was regulated through international customs. In 1955, the ILC decided to codify various international provisions which were then held by the UN General Assembly in 1963 and 1961. From this conference state agreement was obtained and ratification of the Vienna Convention on Consular Relations 1963. However, because of the development of the era, regulation is needed which further emphasizes the importance of protection for each (Bowden, 2006).

The urgency is increasingly supported by various cases which are violations of the Vienna Convention on Consular Relation 1963 or the 1963 Vienna Convention, the existence of developed countries that interfere with the affairs of developing countries, human rights that have not been implemented, and so forth. While the Vienna Conventions of 1961 and 1963 did not regulate entirely about individuals but diplomatic/consular officials. To complement these shortcomings in 2006, the ILC formed a draft on diplomatic protection. Although the ILC Draft Articles on Diplomatic Protection 2006 is still in the form of a draft and has not become an international convention, the implementation of the draft is considered to have the same effect as the convention. The ILC Draft on Diplomatic Protection 2006 consists of 19 articles regulating further protection of individuals with citizenship, individuals without citizenship, refugees, and legal entities. Thus, the arrangement regarding the 


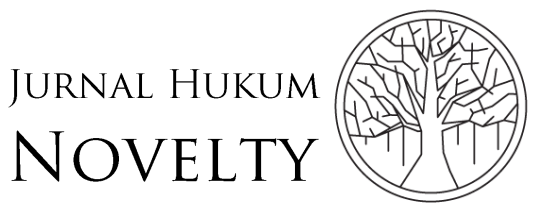

Volume 10, Issue 02, 2019, pp. 85-100
P-ISSN: $1412-6834$

E-ISSN: 2550-0090

diplomatic protection of individuals is increasingly detailed. It is because of this nonbinding nature that causes countries to return to the old mechanism in terms of protecting citizens abroad, one of which is to establish a Mandatory Consular Notification with a placement country.

The definition of diplomatic protection is not clearly stated in the ILC Draft Articles on Diplomatic Protection 2006. Article 1 states that “... diplomatic protection consists of invocation by a State, diplomatic through action or other means of peaceful settlement..." which does not explain the definition but just the procedure. Craig Forcese argues that diplomatic protection is "action taken against another state in terms of the right act or omission attributable to the latter state." In carrying out diplomatic protection, it must first fulfill three things, namely the International Wrong Exhaustion, Exhaustion of Local Remedies, and Link of Nationality. With an explanation, as follows:

1. International Wrong Exhaustion

A country, or in this case, the sending country, is obliged to protect its citizens in other countries if it violates international law (Wittich, 2002). Violations committed can be either direct or indirect violations. As stated in the ILC Draft Articles on Diplomatic Protection 2006 Article 1 concerning the scope and definition:

"For the purposes of the present draft articles, diplomatic protection consists of the invocation by a State, through diplomatic action or other means of peaceful settlement, of the responsibility of another State for an injury caused by an internationally wrongful act of that State to a natural or legal person that is a national of the former State with a view to the implementation of such responsibility."

The article states that diplomatic protection consists of the involvement of a country through diplomatic action as a form of accountability for violations of a country's international law against individuals or legal entities. Also, the legal basis which states the protection of the recipient country to the interests of the sending country is mentioned in Article 3 of the Vienna Convention on Consular Relation 1963. The protection of the interests of the sending country and its citizens is permissible as long as it is below the limits permitted by international law.

2. Exhaustion of Local Remedies

Based on this second condition, every foreign national who experiences unfair treatment by the recipient country can file a claim by taking legal action in that country first. This step must be carried out before it can be submitted to the ICJ on the record that the party that can become a party is a country (Edwards, 2008). This also applies to diplomatic protection which will only be carried out if the citizen has made a local legal effort in the recipient country. This is also regulated in the ILC Draft Articles on Diplomatic Protection 2006 Article 14 Paragraph (1), namely: A State may not present an international claim in respect of injury to a 
national or another person in Draft Article 8 before the injured person has, subject to Draft Article 15, exhausted all local remedies.

3. Link of Nationality

The country that can provide diplomatic protection is the state of the people concerned. This relationship between the state and its citizens is based on the principle of sine qua non which is a traditional rule in diplomatic protection (Faro \& Moraru, 2010). As stated in the ILC Draft Articles on Diplomatic Protection 2006 Article 3 which states that: "The State is called a diplomatic protection exercise, is the State of nationality. Based on this condition, the citizens of the troubled country must have citizenship, which can be seen from birth, descent, state succession, naturalization or other means that do not conflict with international law."

\section{Protection of the Indonesian Government through Mandatory Consular Notification}

The Indonesian government as one of the ratifying conventions on diplomatic and consular still feels that it is not enough to refer to Article 36 of the 1963 Vienna Convention. So that Indonesia continues to intensify cooperation in the Mandatory Consular Notification with various countries, for optimal protection of Indonesian citizens abroad. Indonesia has not yet had a Mandatory Consular Notification with a country with the highest concentration of Indonesian Migrant Worker. Meanwhile there are still many Indonesian citizens who are threatened with capital punishment in countries such as Saudi Arabia, Malaysia and China. Indonesia continues to approach other countries to approve the establishment of the Mandatory Consular Notification, even though the approach has been rejected.

Until now, Indonesia only has Mandatory Consular Notification agreements with Australia, Brunei Darussalam, the Philippines, Costa Rica and Panama, which are not the countries with the highest concentration of Indonesia Migrant Worker. Nevertheless, Indonesia continues to intensify further discussions to form Mandatory Consular Notification together with several countries such as Malaysia, Jordan, Yemen, Taiwan, and so on. Regarding Malaysia, the planned establishment of the Mandatory Consular Notification is done by forming a team of Eminent Person Group (EPG) which is useful for creating understanding between the two countries. The EPG team between Indonesia and Malaysia will consist of experts, community leaders, scholars, cultural experts and scholars.

Although up to now only 5 (five) countries have held MCNs with Indonesia and these five countries are not countries with large numbers of migrant workers, the effort to realize the Mandatory Consular Notification remains important. This is due to the position of Indonesia with a large number of citizens working abroad so that they have a big chance of getting into trouble there. With Mandatory Consular Notification, the enactment of Article 36 of the 1963 Vienna Convention will be stronger, and efforts to protect migrant workers will become easier. In addition, this is based on the experience of Indonesia with several countries in the Middle East such as Saudi Arabia 


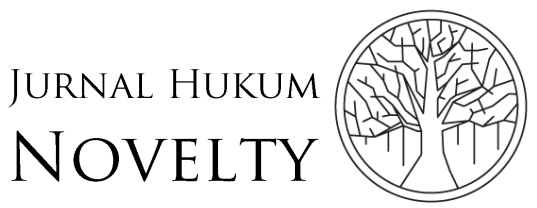

Volume 10, Issue 02, 2019, pp. 85-100
P-ISSN: $1412-6834$

E-ISSN: 2550-0090

and the United Arab Emirates. These countries often have legal issues that affect migrant workers but are not quick to report to Indonesian representatives there. There are also countries that accept Mandatory Consular Notification cooperation with Indonesia and are still under discussion. Another step taken by Indonesia is to intensify the formation of the MoU on labor. For example, the MoU between Indonesia and Saudi Arabia dated February 19, 2014 concerning Placement and Protection of Indonesian Domestic Workers.

As a form of effectiveness of the Mandatory Consular Notification agreement it can be exemplified from the provision of consular notifications from the Indonesian government to the Philippines in the case of illegal fishermen. As many as 544 foreign fishermen were arrested for fishing illegally in Indonesian waters (Oktivana, 2017). After the 544 fishermen were arrested, the Ministry of Foreign Affairs sent officials from the Directorate of International Treaties and the Consular Directorate to assist the process of verifying the fishermen. The results of the verification showed that the majority of the fishermen came from Malaysia and the Philippines. Furthermore, the Ministry of Foreign Affairs immediately conducted a consular notification to the Embassies of the two countries in Jakarta. This is a form of implementing Indonesia's consular obligations to Malaysia even though the two countries do not have a Mandatory Consular Notification agreement. The implementation of obligations was also applied to the Philippines which has a Mandatory Consular Notification with Indonesia on February 24, 2014.

On the other hand, the form of the effectiveness of the Mandatory Consular Notification is quite evident from Indonesian and Australian diplomatic relations. On May 16, 2007 Australian customs vessels arrested as many as 49 fishermen from six Indonesian fishing vessels captured in waters near the Ashmore Marine Park in the Timor Sea (Wuryandari, 2014). But the Indonesian Embassy in Canberra and the Indonesian Consulate in Darwin did not get an arrest notification (notification of apprehension) from the Australian government, and only knew the information about the arrest of Indonesian fishermen from German mass media reports. One week later, the Indonesian Consular Darwin managed to contact one of the fishermen and planned to find out more information about the name of the ship, the number and name of the crew and the catching coordinates. Such detailed information had never been mentioned in an arrest notification even though it had been agreed upon by the governments of both countries.

Australia's good faith regarding the implementation of the Mandatory Consular Notification agreement with Indonesia was seen in the Australian government's recommendation to amend the Migration Act 1958 so that every underage individual would get access to consular assistance as soon as possible after his arrival in Australia. After the establishment of a Mandatory Consular Notification agreement between Indonesia and Australia, a consular notification must be sent by each party if there are problematic citizens within 3 days, this was also conveyed by the Minister 
of Foreign Affairs and Trade of Australia. The recommendation for the amendment of the 1958 Migration Act was motivated by the large number of Indonesian fishermen who were underage and arrested by Australian authorities without informing them of access to consular assistance from the Indonesian Consulate in Australia.

In the case of Tuti Tursilawati, aside of several capacities of consular related to nationals of the sending State as stated in Article 36 of the Vienna Convention on Consular Relations 1963, creating bilateral agreement on Mandatory Consular Notification (MCN) with Saudi Arabia is very important. Formally, Mandatory Consular Notification will be the legal basis for Indonesia to help and give proper protection to the nationals. Without Mandatory Consular Notification, Indonesia are not able to protect the nationals from any cases that happened abroad, especially the criminal cases.

\section{Conclusion}

Apparently, Mandatory Consular Notification agreement is something very critical to be settled by Indonesia and Saudi Arabia to provide guarantees for respectable consular notification procedures in dealing with Tuti Tursilawati execution since Saudi Arabia did not send the notification earlier before the execution. It impacts to the protection of the rights of citizens during the due process of law and Saudi Arabia as a Party of the Vienna Convention on Consular Relations 1963 is firmly infringed the Article 36 of the Convention itself.

Mandatory Consular Notification is the continuation of consular notice; Indonesia shall create bilateral agreement in that issue to give an access and as a form of protection for citizens in other foreign countries around the world. It will prevent the same situations that might happen for Indonesian whenever they stay abroad.

\section{References}

Abass, A. (2014). International law: Text, cases, and materials (Second edition). Oxford, United Kingdom: Oxford University Press.

Amnesty International. (2018). Amnesty international global report: Death sentences and executions 2017. Retrieved from https://bit.ly/34kYTka

Amnesty International. (2019). Amnesty international global report: Death sentences and executions 2017. Retrieved from https://bit.ly/36oNfX9

Ariadno, M. K., \& Rizani, I. (2006). Case concerning avena and other mexican nationals (Mexico vs. United States of America). Indonesian Journal of International Law, 3(3), 443-452. Retrieved from http://ijil.ui.ac.id/index.php/home/article/view/537/pdf_421

Bowden, Brett. (2006). Book review: Antony Anghie. Imperialism, sovereignty and the making of international law. The European Journal of International Law, 17(3), 689-692. https://doi.org/10.1093/ejil/chl017

Buys, C. G., Pollock, Scott D., \& Pellicer, I.N. (2011). Do unto others: The importance of better compliance with consular notification rights. Duke Journal of Comparative and International Law. 21(3), 461-501. Retrieved from https://scholarship.law.duke.edu/djcil/vol21/iss3/1

Edwards, A. (2008). The optional protocol to the convention against torture and the 
detention of refugees. International and Comparative Law Quarterly, 57(4), 789825. https://doi.org/10.1017/S0020589308000596

Faro, S., \& Moraru, M. (2010). Consular and diplomatic protection: Legal framework in the EU member states. Final Report of the CARE (Citizens Consular Assistance Regulation in Europe) Project. https://doi.org/10.2139/ssrn.1998833

Oktivana, D. (2017). Arrest and detention of 'boat people' in Indonesia territory water. Padjadjaran Journal of International Law, 1(1), 68-83. Retrieved from http://jurnal.fh.unpad.ac.id/index.php/PJIL/article/view/37

Wuryandari, G. (2014). Menerobos batas nelayan Indonesia di perairan Australia: Permasalahan dan prospek. Jurnal Penelitian Politik, 11(1), 1-20. Retrieved from http://ejournal.lipi.go.id/index.php/jppol/article/view/188

Gustina, A. (2014). The important of mandatory consular notification between indonesia and other foreign states. Mimbar Hukum, 26(2), 321-331. https://doi.org/10.22146/jmh.16043

ICJ- La Grand Case. (n.d.). Retrieved from https://www.icj-cij.org/files/caserelated/104/7728.pdf

Johnson, D. T., \& Zimring, F. E. (2009). The next frontier: National development, political change, and the death penalty in Asia. Oxford: Oxford University Press.

Kadish, M. J. (n.d.). Article 36 of the Vienna Convention on Consular Relations: A Search for the Right to Consul. 18, 50.

Klabbers, J. (2009). An introduction of international institutional law (2nd Ed). Cambridge, UK; New York: Cambridge University Press.

Medellin v. Texas | LII / Legal Information Institute. (n.d.). Retrieved July 6, 2019, from https://www.law.cornell.edu/supremecourt/text/552/491

Sen, B. (1965). A diplomat's handbook of international law and practice (G. Fitzmaurice, Ed.). Retrieved from https://www.springer.com/gb/book/9789401181594

Shaw, M. N. (2003). International law (5th ed). Cambridge, U.K.; New York: Cambridge University Press.

Veneziano, S. (2017). The right to consular notification: The cultural bridge to a foreign national's due process rights. Georgetown Journal of International Law, 49(1), 501-551. Retrieved from https://www.law.georgetown.edu/international-law-journal/wpcontent/uploads/sites/21/2018/07/GT-GJIL180010.pdf

Wittich, S. (2002). The international law commission's articles on the responsibility of states for internationally wrongful acts adopted on second reading. Leiden Journal of International Law, 15(4), 891-919. https://doi.org/10.1017/S0922156502000390 